\title{
PENINGKATAN PENDAPATAN PETERNAK BEBEK MELALUI PELATIHAN PAKAN TERNAK DAN KEWIRAUSAHAAN
}

\section{INVESTMENT IMPROVEMENT OF DUCK FARMERS THROUGH TRAINING OF ANIMAL FEED AND ENTREPRENEURSHIP}

\author{
${ }^{1)}$ Pasca Dwi Putra, ${ }^{2)}$ Hidir Efendi, ${ }^{3)}$ Wasis Wuyung Wisnu Brata \\ ${ }^{1)}$ Jurusan Pendidikan Tata Niaga, Fakultas Ekonomi \\ 2)Jurusan Pendidikan Teknik Mesin, Fakultas Teknik \\ ${ }^{3)}$ Jurusan Pendidikan Biologi, Fakultas MIPA, Universitas Negeri Medan \\ Jalan Willem Iskandar Psr V- Kotak Pos No.1589 Medan 20221 \\ email : sgacenter@gmail.com
}

\begin{abstract}
ABSTRAK
Tujuan pengabdian kepada masyarakat ini adalah untuk memberikan teknologi tepat guna dalam menghasilkan pakan ternak yang lebih sehat dan alami serta mengurangi penggunaan pakan ternak yang berasal dari pelet. Oleh karena itu, pelatihan dan penyuluhan pembuatan pakan ternak dapat mengurangi biaya pakan ternak dan dapat meningkatkan jumlah produksi telur bebek. Disamping itu, adanya pelatihan ketrampilan bagi peternak dapat meningkatkan kemampuan peternak dalam perencanaan keuangan dan kewirausahaan sehingga peternak dapat lebih mandiri. Hasil pengabdian ini menunjukkan bahwa adanya penggunaan teknologi tepat guna dalam menghasilkan pakan ternak yang alami dapat meningkatkan jumlah telur bebek yang dihasilkan serta membuat bebek lebih tahan terhadap penyakit dan perubahan cuaca. Disamping itu, adanya pembuatan pakan ternak dapat mengurani pengeluaran peternak bebek sehingga dapat meningkatkan pendapatan peternak dari sebelumnya. Pelatihan dan penyuluhan manajemen keuangan dan kewirausahaan juga meningkatkan ketrampilan peternak dalam perencanaan keuangan dan pemasaran telur bebek sehingga dapat meningkatkan penjualan. Penggunaan teknologi dapat mengurangi ketergantungan peternak dalam penggunaan pelet dan meningkatkan pendapatan peternak. Kegiatan pengabdian masyarakat ini menunjukkan bahwa pakan ternak yang dihasilkan sendiri dapat mengurangi dan mengganti pakan ternak yang berasal dari pelet, pelatihan perencanaan keuangan dapat merencanakan usaha peternak kedepan, dan adanya variasi produk dapat meningkatkan pendapatan peternak.
\end{abstract}

Kata Kunci : Pakan Ternak, Teknologi Tepat Guna, Kewirausahaan, Manajemen Keuangan, Variasi Produk

\begin{abstract}
The purpose of community service is to provide the right technology to produce healthier and more natural animal feed and to reduce the use of poultry feed originating from pellets. Therefore, training and counseling of livestock feed can reduce the cost of animal feed and can increase the amount of duck egg production. In addition, the skill training for farmers can improve the capability of farmers in financial planning and entrepreneurship so that farmers can be more independent. The results of this dedication show that the use of appropriate technology in the production of natural livestock feed can increase the number of duck eggs produced and make ducks more resistant to disease and weather changes. In addition, the creation of animal feed can reduce the expense of duck breeders so as to increase the income of farmers from the previous. Training and counseling of financial and entrepreneurial management also improves farmers' skills in financial planning and marketing of duck eggs so as to increase sales. The use of technology can reduce the dependence of farmers in the use of pellets and increase the income of farmers. These community service activities demonstrate that self-produced livestock can reduce
\end{abstract}


and replace poultry feeds from pellets, financial planning training can plan future farmers, and the variety of products can increase farmers' income.

Keywords : Animal Feed, Appropriate Technology, Entrepreneurship, Financial Management, Variaty Product

Submited : 21 Agustus 2017 Revision : 14 Februari 2017 Accepted : 4 Maret 2018

\section{PENDAHULUAN}

Perkembangan perekonomian yang lamban sekarang ini menyebabkan masih sedikit lapangan pekerjaan yang tersedia untuk masyarakat. Tingkat pengangguran yang semakin meningkat sehingga memaksa masyarakat harus menganggur beberapa waktu. Disamping itu, semakin meningkatnya pengangguran menyebabkan semakin tingginya tingkat kriminalitas dan angka kemiskinan sehingga merupakan sorotan utama bagi pemerintah untuk mengatasi masalah tersebut. Oleh karena itu, perlu penyelesaian masalah dengan berwirausaha untuk dapat menciptakan lapangan kerja dan menghasilkan pendapatan serta meningkatkan kesejahteraan bagi masyarakat. Salah satunya dengan beternak yang mempunyai potensi dan peluang ekonomi yang sangat besar.

Di Indonesia, bebek merupakan salah satu unggas yang banyak di pelihara oleh masyarakat menengah kebawah dipedesaan. Hal ini karena bebek memiliki banyak manfaat dan tidak rumit untuk dipelihara. Pernyataan ini juga didukung oleh pendapat Hardjosworo (2002) bahwa itik/ bebek merupakan ternak pertama yang dibudidayakan sebagai sumber pendapatan.

Disamping itu, bebek mempunyai daya tahan yang lebih baik dibandingkan unggas lainnya. Adapun manfaat yang dapat diperoleh masyarakat melalui telur yang dihasilkan baik untuk dijual maupun dikonsumsi, bebek juga dapat dijual. Harga jual bebek lebih tinggi dibandingkan ayam yang biasa dipelihara oleh masyarakat.

Masyarakat pedesaan dan menengah kebawah merupakan mayoritas pemelihara bebek sebagai penompang hidup mereka. Oleh karena itu, program pengabdian masyarakat ini ditujukan pada kelompok masyarakat khususnya peternak bebek dipedesaan untuk meningkatkan kesejahteraan mereka.

Salah satunya masyarakat yang beternak bebek di Desa Kolam Kecamatan Percut Sei Tuan Kabupaten Deli Serdang. Desa Kolam merupakan desa yang wilayahnya terletak di Provinsi Sumatera Utara memiliki kondisi geografi cocok untuk pertanian dan peternakan. Pada wilayah ini, mata pencaharian masyarakat mayoritas bercocok tanam seperti padi, jagung, ubi, dan lainnya. Adanya tanaman tersebut wilayah Desa Kolam cocok juga untuk dilakukan ternak unggas seperti bebek, ayam, dan lainnya. Karena sumber makanannya banyak berasal dari daerah pertanian seperti keong, cacing, dan lainnya. Oleh karena itu, banyaknya potensi yang dimiliki Desa Kolam dapat meningkatkan kesejahteraan dan perekonomian masyarakat setempat.

Saat ini, masyarakat desa hanya berfokus pada pertanian sehingga perlu dikembangkan lagi usaha lain seperti ternak bebek. Hal ini karena bebek mempunyai nilai yang lebih tinggi produknya mulai dari daging hingga telur yang dihasilkan. Ternak bebek di Desa Kolam masih sangatlah jarang dikarenakan 
dibutuhkan modal yang cukup besar dimulai dari pembuatan kandang sampai pakan dan pemeliharaan.

Disamping itu, dalam menjalankan usaha peternakan tersebut, banyak masalah yang dihadapi peternak seperti kurangnya pengetahuan peternak dalam manajemen keuangan dan kewirausahaan, pakan ternak yang menghasilkan banyak produksi telur, serta variatif dari produksi telur tersebut.. Perlunya penyelesaian masalah tersebut agar masyarakat dapat merencanakan dan mengembangkan ternaknya kedepan sehingga dapat meningkatkan kesejahteraan.

Kurangnya pengetahuan masyarakat mengenai ternak dan perencanaan menyebabkan biaya yang dikeluarkan peternak besar. Oleh karena itu perlu dilakukan pelatihan dan penyuluhan kepada masyarakat agar biaya yang dikeluarkan dalam beternak bebek dapat ditekan. Salah satunya dengan membuat pakan ternak dengan menggunakan teknologi tepat guma melalui mesin pembuatan pakan ternak. Masyarakat yang hanya mengandalkan pelet sebagai pakan ternak akan menyebabkan biaya yang besar dan tidak sebanding dengan telur yang dihasilkan. Oleh karena itu, masyarakat dapat membuat pakan ternak dengan bahan-bahan yang tersedia dan murah seperti jagung, dedak, ampas tahu, dan bahan alami yang dapat menambah jumlah produksi telur. Penelitian yang dilakukan oleh Reppy, et al (2000) dengan mengintroduksi ransum dengan komposisi $30 \%$ jagung, $40 \%$ dedak halus dan $30 \%$ kosentrat dengan kadar protein $16,68 \%$ diperoleh hasil konsumsi ransum 176,5 gr/ek/hari, sedangkan pakan teknologi petani 173,55 gr/ek/hari. Produksi telur meningkat dari $51,75 \%$ menjadi $68,65 \%$, berat telur meningkat dari 69,4 gr menjadi72,25 gr, konversi pakan turun dari 2,54 menjadi 2,40. Pentingnya pakan yang berkualitas dan jumlah yang cukup akan mendorong ternak bebek untuk memproduksi telur lebih banyak sesuai dengan penelitian yang dilakukan oleh Rochjat (2000)

Disamping itu, perlunya pelatihan manajemen keuangan dan kewirausahaan. Menurut Suryono dan Sumarno (2013) bahwa kewirausahaan menyangkut tiga komponen yaitu pembelajaran kewirausahaan, adanya incubator wirausaha, dan sentra kewirausahaan. Sedangkan menurut Jong dan Wenekers (2008) bahwa kewirausahaan merupakan pengambilan risiko dengan melihat peluang yang ada untuk menciptakan usaha baru atau pendekatan yang inovatif sehingga menjadikan usaha lebih berkembang besar dan mandiri dalam menghadapi pesaing. Pada akhirnya pentingnya pengetahuan tentang kewirausahaan pada peternak akan mendorong peternak bebek untuk meningkatkan pendapatan melalui praktik kewirausahaan.

Adapun praktik kewirausahaan yang dilakukan yaitu dengan melakukan pelatihan mengenai perencanaan keuangan dalam hal pembiayaan pakan ternak, perawatan, ataupun perbaikan kandang ternak. Oleh karena itu, perlu dilakukan pelatihan dan penyuluhan mengenai manajemen keuangan, kewirausahaan, dan pembuatan pakan ternak. Variatif produk telur merupakan usaha untuk menambah nilai produk telur sehingga menghasilkan harga jual yang lebih tinggi. Selama ini peternak bebek hanya menjual telur dan harganya terkadang merugikan peternak sehingga perlu dilakukan variatif produk yang pada akhirnya meningkatkan pendapatan bagi peternak. Seperti yang dikatakan oleh Harper (1991) bahwa suksesnya suatu usaha memerlukan kemampuan membaca peluang, memiliki keahlian dan kemampuan pada bidang yang ditekuni, melakukan pendekatan dalam menjalankan usaha, dan memiliki modal yang cukup. 
Perguruan tinggi sebagai fasilitator mengatasi masalah tersebut dengan cara memberikan teknologi tepat guna dan pengetahuan. Keterbatasan alat dapat diatasi dengan penggunaan mesin pembuatan pakan ternak. Keterbatasan biaya diatasi dengan penggunaan bahan baku pembuatan pakan ternak yang tersedia dialam. Keterbatasan jumlah produksi telur diatasi dengan menggunakan pakan yang dapat menambah jumlah produksi telur. Oleh karena itu, kegiatan ini akan meningkatkan jumlah produksi dan mengurangi biaya yang dikeluarkan untuk pakan ternak serta keahlian manajemen keuangan dan kewirausahaan peternak yang pada akhirnya meningkatkan pendapatan dan kesejahteraan peternak di Desa Kolam Kecamatan Percut Sei Tuan Kabupaten Deli Serdang Provinsi Sumatera Utara.

\section{METODE}

Kegiatan ini dilakukan pada peternak bebek di Desa Kolam Kecamatan Percut Sei Tuan Kabupaten Deli Serdang, Sumatera Utara. Adapun metode yang digunakan pada kegiatan ini adalah dengan cara memberikan pelatihan dan penyuluhan mengenai pembuatan pakan ternak yang meningkatkan produksi telur bebek serta bagaimana mengelola usahanya dimulai dengan perencanaan keuangan sampai praktik kewirausahaan. Dalam memberikan pelatihan dan penyuluhan, menggunakan alat seperti mesin pembuat pakan ternak, dan bahan pembuat pakan ternak lainnya seperti jagung dan ampas tahu. Disamping itu, peserta juga diberikan simulasi bagaimana merencanakan keuangan sehingga peserta lebih mudah merencanakan kedepan.

\section{HASIL DAN PEMBAHASAN}

\section{Pelatihan dan Penyuluhan Manajemen Keuangan dan Kewirausahaan}

Dalam penyampaian topik
mengenai manajemen keuangan dan
kewirausahaan, tim berkoordinasi
khususnya ahli dibidang ekonomi untuk
menyampaikan proses manajemen
keuangan dan kewirausahaan. Pembicara
menyampaikan proses dari perencanaan
keuangan yang diawali dengan membuat
anggaran untuk pengeluaran. Pembuatan
anggaran untuk pengeluaran bertujuan agar
peternak mengetahui jumlah pengeluaran
yang akan dikeluarkan khususnya untuk
pakan dan perawatan ternak dan
kandangnya. Tujuan dibuatnya
pengeluaran agar membatasi biaya yang
dikeluarkan biaya yang tidak memberikan
manfaat bagi peternak dan menjadi beban
yang besar. Perencanaan penerimaan kas
dilakukan untuk mengetahui jumlah
cashflow yang akan terjadi pada
perusahaan sehingga akan diketahui
perusahaan mengalami keuntungan atau
kerugian.

Dari hasil penyuluhan dan pelatihan bahwa kelompok ternak mulai mengetahui pentingnya dilakukan manajemen keuangan yang dimulai dengan perencanaan keuangan. Hal ini berkaitan dengan pengeluaran yang akan terjadi oleh peternak. Disamping itu juga, pada penyuluhan kewirausahaan dijelaskan caracara untuk mengembangkan usaha untuk menjadi lebih baik yang dimulai dengan peningkatan jumlah asset, pemasaran dan termasuk didalamnya perencanaan keuangan dalam mengembangkan usahanya. Hasilnya pada penyuluhan kewirausahaan ini bahwa peternak mulai merencanakan pengembangan usahanya mulai dari membangun kandang, menambah jumlah bebek, dan memperluas wilayah pemasaran. Dengan begitu diharapkan peningkatan perekonomian dan kesejahteraan peternak meningkat. Hasil ini sejalan dengan penelitian yang dilakukan oleh Sulistiyowati dkk (2016) 
yang menunjukkan bahwa pelatihan dapat meningkatkan kapasitas dalam bidang kewirausahaan dan adanya peningkatan kualitas produk. Sejalan juga dengan kegiatan yang dilakukan oleh Susilo, dkk (2017) dimana pelatihan mampu meningkatkan jiwa kewirausahaan.

\section{Pembuatan Pakan Ternak Melalui Teknologi Tepat Guna Untuk Meningkatkan Jumlah Produksi}

Pada pembuatan pakan ternak, tim menggunakan teknologi tepat guna berupa mesin pembuat pakan ternak. Tujuannya untuk mengurangi ketergantungan peternak terhadap penggunaan pelet sebagai pakan bebek. Disamping itu, pembuatan pakan ternak melalui bahan-bahan yang telah disiapkan akan menambah jumlah produksi telur dan mengurangi pengeluaran pakan yang merupakan pengeluaran terbesar bagi peternak hingga mencapai $80 \%$. Pada proses pembuatan pakan ternak ini tim terlebih dahulu memberikan informasi mengenai pakan ternak beserta kandungan dari masing-masing bahan.

Penyediaan pakan untuk itik yang dipelihara secara intensif sering menjadi kendala dalam peralihan cara pemeliharaan dari tradisional ke intensif, karena itik yang dipelihara secara intensif biasanya diberi pakan produksi pabrik atau pakan komersial yang menghabiskan $60-70 \%$ biaya produksi. Hal ini merupakan beban yang cukup berat apabila itik yang dipelihara hanya berproduksi rata-rata kurang dari $60 \%$. Keadaaan ini memacu peternak untuk menyusun ransum itik sendiri. Penggunaan pakan komersial hanya terbatas untuk itik periode awal (umur 0-28 hari), hal ini berkaitan dengan alasan yang sifatnya ekonomis, disamping karena bahan baku pakan itik tidak mudah diperoleh.

Pada pemeliharaan itik intensif semua kebutuhan zat gizi untuk pertumbuhan atau bertelur harus diberikan oleh peternak sehingga biaya yang dibutuhkan untuk pembelian pakan cukup tinggi. Oleh karena itu pemberian pakan yang murah dan memenuhi kebutuhan zat gizi sangat perlu untuk menunjang keberhasilan usaha peternakan itik. Zat gizi yang dibutuhkan oleh itik untuk dapat hidup, bertumbuh dan bertelur adalah: air, protein, sumber energi (lemak dan karbohidrat), vitamin dan mineral.

Banyak bahan pakan alternatif (bahan pakan pilihan) yang bisa digunakan, namun dalam mencari bahan yang akan dipakai hendaknya berpegang pada kadar protein dan energi yang diperlukan itik. Bahan pakan sumber energi untuk itik antara lain adalah dedak padi, jagung, menu, tepung singkong, polar, nasi keying, roti afkir dan mie afkir, namun dalam pemberiannya sebaiknya tidak dalam bentuk keying, tetapi agak basah atau jika terlalu keras perlu direndam sebelum diberikan pada itik. Sebagai contoh perendaman diperlukan jika itik diberi nasi kering, sehingga nasi tersebut menjadi agak lunak/lembek dan dapat ditelan dengan mudah oleh itik.Bahan pakan sumber protein yang sangat disukai oleh itik dalam bentuk segar adalah ikan rucah, cangkang udang dan keong, namun pemberiannya haruslah dalam ukuran yang cukup kecil untuk memudahkan itik menelannya. Adapun pembuatan pakan ternak ini dimulai dengan menggiling dan mencampurkan bahan kering menjadi satu. Tujuannya agar mudah dicerna oleh bebek. Kemudian campurkan bahan yang basah ke bahan yang kering tersebut dan tambahkan air secukupnya. Tujuan ditambahkan air, agar bebek mudah mencerna makan tersebut. Setelah dilakukan simulasi dan pembuatan pakan ternak, adanya sedikit perubahan dari bebek dimana bebek masih belum menerima jenis makanan tersebut dikarenakan bebek tidak cepat beradaptasi terhadap makanan yang baru disamping makanan yang sering dimakan. Oleh 
karena itu, perlu makanan pendamping yaitu makanan yang sering dimakan agar bebek dapat perlahan-lahan berpindah pakannya. Pada beberapa hari kemudian, dari hasil pengamatan bebek sudah memulai untuk menyukai jenis pakan baru ini. Sehingga peternak bisa perlahan-lahan mengganti pakan ternak pelet yang biasa dimakan bebek menjadi pakan ternak yang dihasilkan sendiri. Jumlah telur yang dihasilkan juga sudah mulai meningkat disamping jumlah pakan yang diberikan sesuai dengan kebutuhan bebek. Hasil kegiatan ini sejalan dengan Sugiyanto dan Ratih (2017) dan Susita, dkk (2012) yang menunjukkan adanya rekayasa mesin untuk pembuatan pakan ternak akan meningkatkan produksi pakan ternak lebih banyak dan sesuia dengan harapan.

\section{Variasi Produk}

Dalam pelaksanaan pelatihan pembuatan variasi produk telur bebek tim membuat telur asin sebagai produk yang banyak digemari oleh masyarakat. Tim menggunakan bahan seperti air, garam, abu sekam atau batu bata yang telah dihaluskan. Adapun tujuan dari air sebagai pencampur bahan agar menjadi pasta. Disamping itu, garam berfungsi sebagai bahan utama untuk membuat asin telur, dan batu bata atau abu sekam berfungsi sebagai penutup telur pada saat proses pengasinan. Pada proses pembuatan telur asin dibutuhkan 4-5 hari sesuai tingkat keasinan dari telur. Disamping itu, adanya variatif dari telur bebek dengan membuat menjadi telur asin akan meningkatkan penjualan dan manarik konsumen untuk membelinya. Hasil kegiatan ini didukung oleh Lukito, dkk (2012). Disamping itu kegiatan yang dilakukan oleh Andriani (2014) yang menunjukkan bahwa pentingnya variatif dari makan untuk meningkatkan perekonomian dan kesehatan publik.

\section{SIMPULAN}

Kesimpulan dari kegiatan ini adalah masyarakat khususnya peternak bebek dapat lebih meningkatkan ternaknya khususnya dalam hal manajemen keuangan, kewirausahaan, pembuatan pakan ternak dan variasi produk. Peternak sudah mulai menghitung perencanaan kedepan dan memperluas usaha dan pemasarannya. Peternak juga sudah memulai menggunakan pakan ternak yang dibuat sendiri dan mengurangi ketergantungan pakan ternak dari pelet yang harganya cukup mahal. Serta peternak mulai memvariasikan hasil produknya ke telur asin agar dapat meningkatkan pendapatan bagi peternak tersebut.

\section{DAFTAR PUSTAKA}

Andriani. T, (2014). Pelatihan Pengolahan Ikan Patin Menjadi Makanan variatif dan Produktif di Desa Sawah Kecamatan Kampar Utara Kabupaten Kampar. Jurnal Kewirausahaan, 13, (1).

Hardjosworo, P.S., A. R. Setioko, P. P. Ketaren, L. H Prasetyo, A. P. Sinurat dan Rukmiasih. (2002). Pengembangan teknologi peternakan unggas air di Indonesia. Prosiding Lokakarya Unggas Air: Pengembangan Agribisnis Unggas Air sebagai Peluang Usaha Baru. Bogor, 6-7 Agustus 2001. P. 22-41

Harper, S. J. (1991). The Political Business Cycle Andv Fiscal Policy In Canada. The University of Calgary.

Jong de, J., and S. Wennekers. (2008) Intrapreneurship: Conceptualizing Entrepreneurial Employee Behaviour. Zoetermee: scale 
Lukito. G.A., Suwarastuti.A, dan Hintono, A. (2012). Pengaruh Berbagai Metode Pengasinan Terhadap Kadar $\mathrm{NaCl}$, Kekenyalan dan Tingkat Reppy R, P. Paat, Wenas. J, Tumbel, Mardiana, dan V. Turambi (2000). Penelitian Adaptif Usaha Ternak Itik di Sulawesi Utara. Laporan Hasil Penelitian IPPTP Kalasey Manado.

Rochjat. (2000). Penyusunan Ransum Untuk Itik Petelur. Badan Penelitian dan Pengembangan Pertanian. Instalasi Penelitian dan Pengkajian Teknologi Pertanian. Jakarta.

Sugiyanto dan Ratih, Y. S, (2017). Rekayasa Mesin untuk Industri Kecil Pakan Ternak Unggas di Klaren. Prosiding Snatif ke 4 Tahun 2017.

Sulistiyowati. W, Agustini. I, \& Fitriyah, H. (2016). Peningkatan Kapasitas Entrepreneueship Melalui Pelatihan dan Magang Bagi Tenant di Universitas Muhammadiyah Sidoarjo. Jurnal Pengabdian Pada Masyarakat, 1, (1), 1-5
Kesukaan Konsumen Pada Telur Puyuh Asin. Animal Agriculture Journal. 1, (1), 829-838.

Suryono, Y., \& Sumarno. (2013). Pembelajaran Kewirausahaan Masyarakat. Yogyakarta: Aditya Media

Susilo. D. D, Widodo. Joko. P \& Ubaidillah. (2012) Mekanisasi Proses Pencacahan Bahan Pakan Ternak Dalam Pembuatan Pakan Ternak Fermentasi. Mekanika. 11, (1), 31-38

Susita. D, Mardiyati. U, \& Aminah. H, (2017). Pelatihan Kewirausahaan Bagi Pelaku Usaha Kecil dan Binaan Koperasi di Rumah Susun Sederhana Sewa (RUSUNAWA) Cipinang Besar Selatan. Jurnal Pemberdayaan Masyarakat Madani (JPMM), 1, (1), 58-72

https://www.bps.go.id/brs/view/id/1229 diakses tanggal 1 Mei 2017

https://www.bps.go.id/Brs/view/id/1378 diakses tanggal 